Bioscientia Medicina: Journal of Biomedicine \&

Translational Research

Journal Homepage: www.bioscmed.com

\title{
Overview of COVID-19 Vaccine Development Strategy
}

\section{Katerine Junaidi ${ }^{*}$, Dewi Wahyu Fitrina ${ }^{1}$, Fenty Anggrainy ${ }^{1}$, Deddy Herman ${ }^{1}$}

${ }^{1}$ Department of Pulmonology and Respiration Medicine, Faculty of Medicine, Andalas University/Dr. M. Djamil General Hospital, Padang, Indonesia

\section{A R T I C L E I N F O}

Keywords:

COVID-19

SARS CoV-2

Vaccines

Safety

Clinical trial

*Corresponding author:

Katerine Junaidi

E-mail address:

keket_10@yahoo.com

All authors have reviewed and approved the final version of the manuscript.

\section{https://doi.org/10.37275/bsm.v6i3.473}

\begin{abstract}
A B S T R A C T
Severe acute respiratory syndrome coronavirus 2 (SARS-CoV-2) was identified as the cause of coronavirus disease 20019 (COVID19) pandemic which first emerged in December 2019 in Wuhan city, China. Currently, a vaccine is urgently needed to control the COVID-19 pandemic. Several vaccine candidates are under development and some are in the final stage of clinical trials. The COVID-19 vaccination aims to reduce morbidity and mortality rates, achieve herd immunity to prevent and protect the society, strengthen the health system, maintain productivity and minimize social and economic impacts. Before approval, vaccines have to undergo several clinical trials to ensure its safety profile, efficacy, duration of immune system resistance, and adverse effect. Various strategies have been used in the development of vaccines including viral vector vaccines, nucleic acid vaccines, inactivated virus, live attenuated virus, subunit protein $_{\triangleleft}$ and virus-like particle vaccine. Each strategy has its own advantages and disadvantages.
\end{abstract}

\section{Introduction}

Coronavirus Disease 2019 (COVID-19) is an infectious disease caused by Severe Acute Respiratory Syndrome Coronavirus 2 (SARS-CoV-2). COVID-19 was declared a global pandemic on March 11, 2020, by the World Health Organization (WHO), spreading to 213 countries with a total of 259 million confirmed cases and 5.1 million deaths as of November 26, 2021.1,2 The SARS-CoV-2 virus is classified in the betacoronavirusgroup, the same group of viruses that caused the Severe Acute Respiratory Syndrome coronavirus (SARS) in 2003 and Middle East Respiratory Syndrome (MERS) in 2012. The spread of SARS-CoV-2 has reached 40 times. times that of SARSCoV.2

One of the efforts to achieve herd immunity and reduce the rate of spread is by giving vaccines. ${ }^{3}$ Vaccines are materials containing bacteria, viruses, or other components resembling antigens that cause disease that has been controlled by technological advances. Vaccination aims to obtain active immunity against an antigen so that when a person is exposed to the same antigen, antibodies are formed that will immediately recognize the antigen. Acquired immunity is established at the individual level through natural infection with pathogens or through immunization with vaccines $^{2}$. Herd immunity comes from individual immunity which will later become immunity at the population level. Herd or population immunity is a condition in which a population can be protected from the spread of an infectious disease by reaching the 
threshold of the proportion of the population that gets immunity. If the proportion of the population that is immune to the disease is greater than the threshold, the spread of the disease will decrease. The threshold value for the proportion of the population to achieve herd immunity varies with each disease, the more infectious a disease is, the greater the threshold for the proportion of the population that must acquire immunity to stop its spread. For example, in highly contagious measles, about $94 \%$ of the population must be immune to break the chain of transmission. 4

The study by Bartsch et al found that to establish herd immunity against COVID-19, the vaccine must have at least $70 \%$ efficacy and cover $75 \%$ of the population, however, this figure may change as the proportion of the population exposed to and receiving immunity increases. ${ }^{5}$ Based on WHO data, the number of vaccines that have been given to populations around the world is 7.70 billion doses as of November 26, 2021, and in Indonesia, as many as 208 million doses of vaccine have been used as of November 26, 2021.1 $52.3 \%$ of the world's population has received at least one dose of the COVID-19 vaccine. ${ }^{6}$ The national target for vaccination targets in Indonesia is around 208 million people, with a vaccination ratio of 67 as of November 26, 2021, with a percentage of $66.55 \%$ of the first dose of vaccination and $45.36 \%$ of the second dose of vaccination. ${ }^{7}$

According to WHO data, there are 132, vaccine candidates, in the clinical development stage and 194 in the pre-clinical stage, with various platforms, the most of which are protein subunits, non-replicating viral vectors (VVnr), deoxy nucleic acid (DNA), inactivated viruses, and ribonucleicacid (RNA), viral vector replicating (VVr), virus-like particle (VLP), viral vector replicating + antigen-presenting cell (VVr+APC), live attenuated virus (LAV), non-replicating viral vector + antigen-presenting cell (VVnr+) APC), the bacterial antigen-spore expression vector (BacAg-SpV).8 All COVID-19 vaccine candidates are made to elicit an immune response mediated by neutralizing antibodies (nAbs) against S . protein SARS-CoV-2. Protein S helps the attachment of the virus to the ACE2 receptor on the surface of the host cell and initiates fusion between the virus and the cell membrane. 9 Based on the above background, the author is interested in discussing the basic mechanism of action of the COVID-19 vaccine, the vaccine development stage, and the 5 most common platforms in the clinical development phase.

\section{SARS-CoV-2}

SARS-CoV-2 is a single-chain RNA virus, belonging to the family coronavirus (CoVs) that has been discovered since 1960. This virus can infect humans and animals, causing disorders of the respiratory, hepatic, gastrointestinal, and neurological systems. ${ }^{10}$ The spread of SARS-CoV-2 occurs as a result of close human-to-human contact through droplets. Respiratory and airborne droplets are the main factors of virus transmission. Based on the severity, the disease can be divided into mild, moderate, severe, and critical symptoms. Mild symptoms include dry cough, low-grade fever, stuffy nose, sore throat, and muscle aches. Moderate symptoms are shortness of breath and tachypnea, while severe symptoms show signs of respiratory distress, respiratory failure, septic shock, or multiple organ failure. 10,11

\section{Structure of SARS-CoV-2}

The structure of the viral genome consists of 4 main antigenic proteins, namely spike (S), envelope (E), membrane $(\mathrm{M})$, and nucleocapsid $(\mathrm{N})$ proteins as shown in Figure 1. E and $\mathrm{M}$ proteins form the structure of the outermost membrane of the virus while the $\mathrm{N}$ protein forms an RNA structure that functions for virus replication. Protein $\mathrm{S}$ is on the surface of the virus resembling a crown-like spike with a trimeric shape, where it binds to the viral angiotensin-converting enzyme (ACE) 2 receptor which is found on various cell surfaces of the human body. Protein $\mathrm{S}$ has a size of 180-200 kDa, coated with polysaccharide molecules that can disguise viruses from the body's immune system. Protein $\mathrm{S}$ is the main antigen that plays a role in receptor recognition, adhesion to the entry of viruses into cells. The body's defense response to protein $\mathrm{S}$ is the key to host protection against SARS-CoV-2 which is the basis for vaccine development. 12,13 


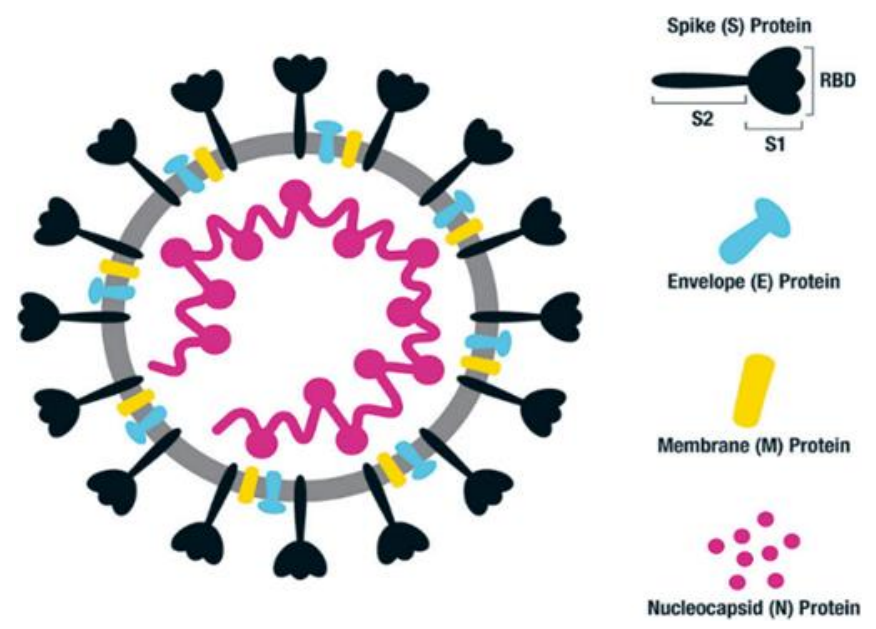

Figure 1. The structure of the SARS-CoV-2 virus and the main components of the antigen. ${ }^{12}$

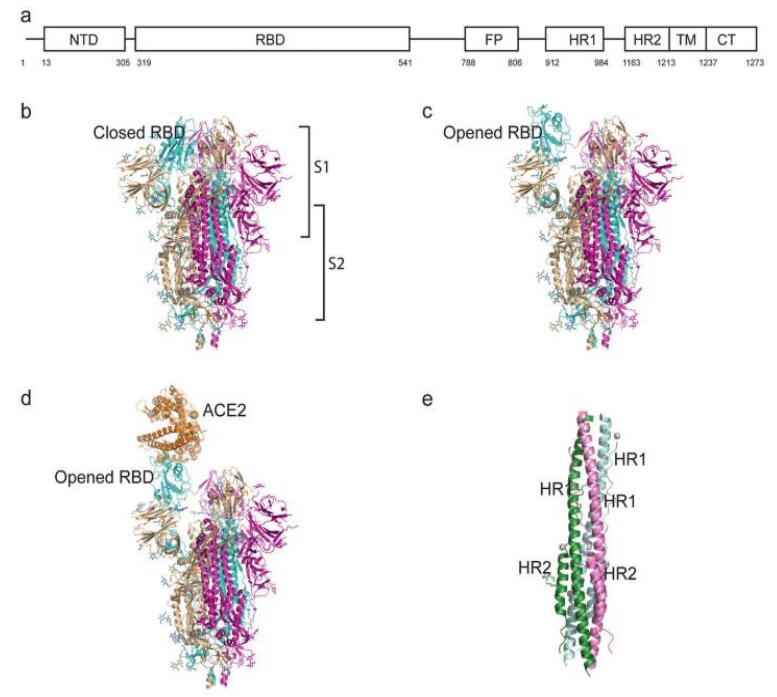

Figure 2. The structure of the S protein SARS-CoV-2 is based on analysis of cryogenic electron microscopy (Cryo$\mathrm{EM})$. A. the structure of the S protein in the form of a schema. b-c. RBD protein $\mathrm{S}$ is closed and open. $\mathrm{d}$. S proteins bind to open RBD in the S1 subunit. e. the 6-helix structure formed by HR1 and HR2 of the S2 subunit.13

The S protein consists of the S1 subunit and the S2 subunit as shown in Figure 2. The $\mathrm{S} 1$ protein has 3 domains, namely signal peptide (SP), receptor-binding domain (RBD), an N-terminal domain (NTD). The Signal Peptide domain consists of 13 amino acids with hydrophobic properties that serve to guide the transport of the virus to the cell membrane. The $\mathrm{N}$ terminal domain containing the signal peptide and RBD strands functions to bind to the ACE2 receptor on the surface of the host cell. The receptor-binding domain is the core domain of the $\mathrm{S} 1$ protein and is where the virus binds to the ACE2 receptor. The RBD domain can be embedded in the inner side, in this phase, it is known to be in a hidden downstate and the $\mathrm{S} 1$ subunit can rotate to the top side if it will bind to the ACE2 receptor. The hidden downstate is the predominant state of the SARS-CoV-2 protein $\mathrm{S}$, and the virus uses this mechanism to hide the epitope and evade the immune response. 12.14

The S2 protein functions in the fusion process in the cell membrane and facilitates the entry of viruses into the cell. The S2 protein consists of a fusion peptide domain (FP), an internal fusion peptide (IFP), two heptad-repeat domains (HR1 and HR2), a transmembrane domain, and a C-terminal.12,14 Membrane fusion requires two sides, namely the virion side and the other side on the host cell, the $\mathrm{C}$ terminal domain is on the virion side and the FP domain will penetrate the target cell membrane. ${ }^{14}$ Two heptadrepeat domains are domains consisting of hepta 
peptides that repeat to form a six-helical bundle (6-HB) which are used for fusion and entry of viruses into cells.

The FP domain appears after attachment and change to the S protein and will trigger viral fusion into cells. The distance between the viral membrane and the cell membrane shortens, the HR1 domain on the $\mathrm{S}$ protein is close to the host cell membrane, while the HR2 domain is on the side of the viral membrane, then HR2 will fold to the side of the HR1 domain and form a 6-HB structure. The viral membrane is pushed towards the host cell membrane and binds until it sticks and then there is a fusion of the two membranes. ${ }^{13}$

The SARS-CoV-2 virus enters cells by binding to the ACE2 receptor and transmembrane protease serine 2
(TMPRSS2) on the surface of the cell membrane (Figure 4). The S2 subunit of the virus allows for the fusion of the virus and the cell membrane. The virus enters the cell cytoplasm by endocytosis. The viral RNA genetic material will be released and enter the replication stage which begins with the translation of the genetic code into a complex transcriptional protein by ribosomes and the arrangement of protein and nucleocapsid structures in the endoplasmic reticulum Golgi intermediate compartment (ERGIC). This process will produce a new virus with complete RNA that will be released from the cell. ${ }^{15}$

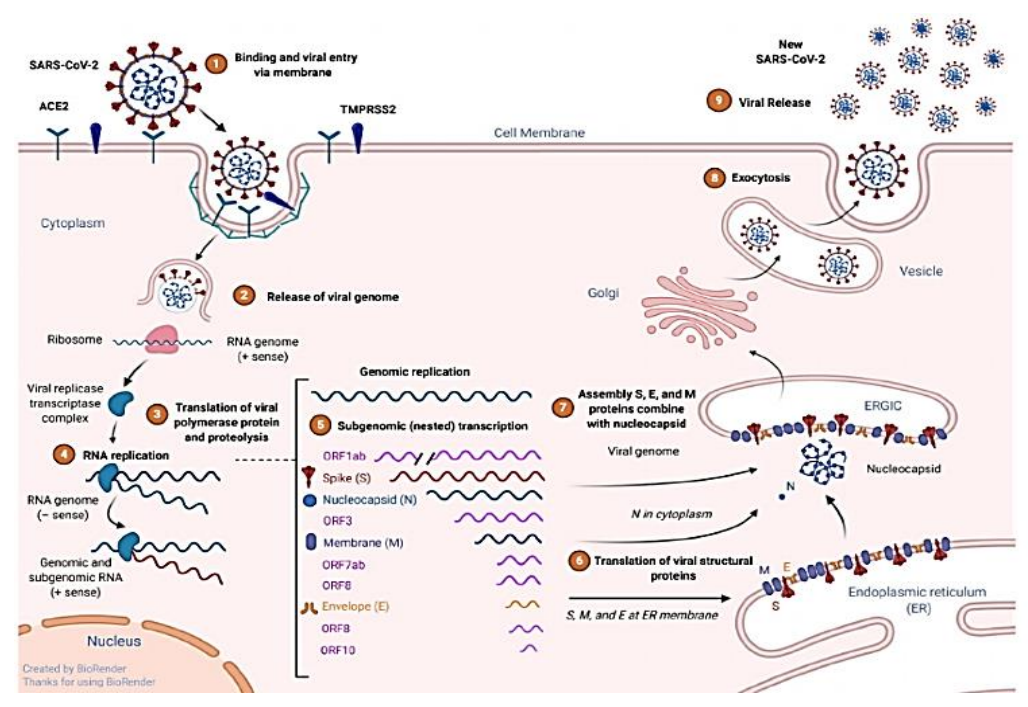

Figure 3. Replication of SARS CoV-2.15

\section{Immune response to COVID-19}

Stimulation of various immune responses by SARSCoV-2 is associated with pattern-associated molecular patterns (PAMPs). Antigen-presenting cells such as monocytes, macrophages, and dendritic cells recognize the molecular patterns expressed by SARS-CoV-2 through pattern recognition receptors (PRRs) such as endosomal toll-like receptors (TLRs) 3 and 7, cytosolic retinoic acid-inducible gene 1 (RIG-1), and melanoma differentiation-associated protein 5 (MDA5). The recognition of the molecular pattern will activate intracellular signals which will eventually activate interferons 1 and 3 , produce pro-inflammatory cytokines, chemokines and will activate neutrophils and other natural immune cells such as natural killer (NK) cells. 12

Damage to local tissues will also release damageassociated molecular patterns cells, memory $\mathrm{T}$ cells, and B cells. 6 immuneNatural factors that play a role in SARS-CoV-2 are shown in Figure 5. 


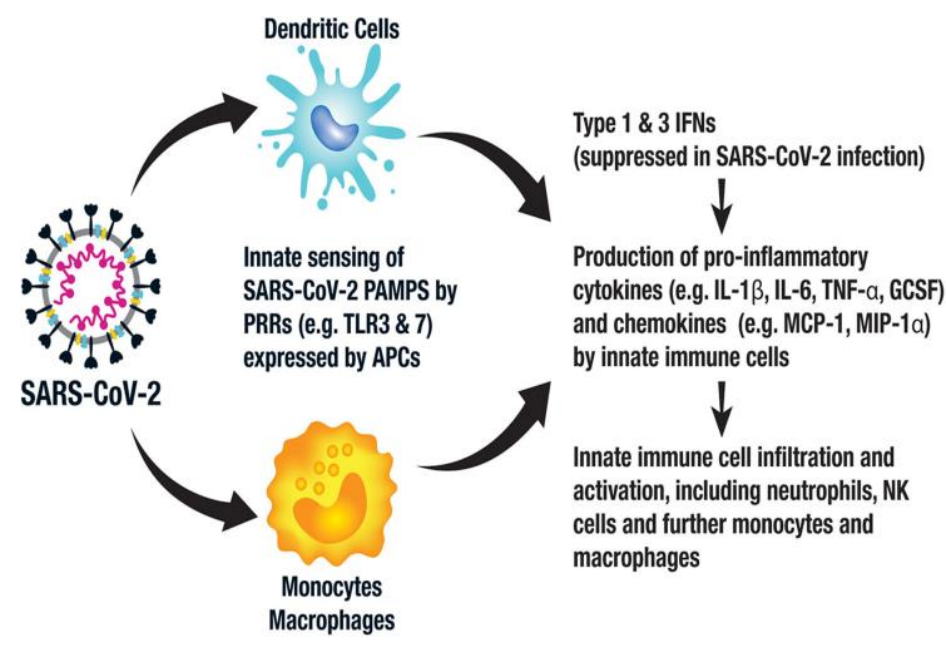

Figure 4. The main components of the natural immune response to SARS-CoV-2.12

Epithelial cells will be damaged and lysed when the SARS-CoV-2 virus enters and replicates in the cells. immune system adaptive that play a role in SARS-CoV2 are shown in Figure 6. Antigen-presenting cells such as tissue macrophages and especially dendritic cells will present epitope/viral antigens through Major Histocompatibility Complex (MHC) class I to activate Cluster Differentiation (CD) 8 naive and CD4 T cells via MHC class II. T cells that differentiate into cytotoxic CD8 $\mathrm{T}$ cells will destroy infected cells through cellular apoptosis by producing granzymes and perforins. CD4 $\mathrm{T}$ cells differentiate into $\mathrm{T}$ Follicular (Th) 1, Th17, and
T Helper (TFH). Th1 and Th17 CD4 cells play an important role in the inflammatory process in the innate immune response and viral destruction. Regulatory $\mathrm{T}$ cells (Treg) act as immunoregulators in SARS-CoV-2 infection by producing anti-inflammatory cytokines. T helper 2 CD4 helps B cells to produce antibodies. TFH cells help B cells become Plasma Cells (PCs) to form specific antibodies or Immunoglobulins (Ig). Specific antibodies formed in the form of IgM, IgA, and IgG. The overall immune response to SARS CoV-2 can be seen in Figure 7.11.14

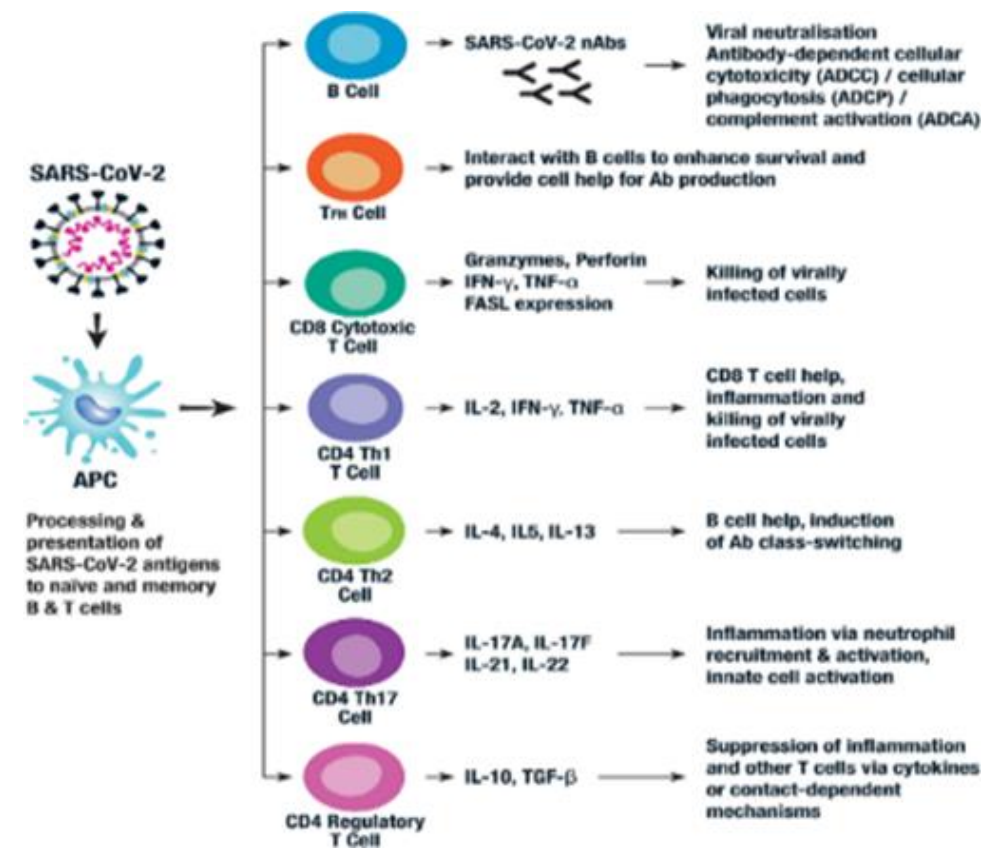

Figure 5. The main components of the adaptive immune response to SARS CoV -2.12 
The incubation period for SARS-CoV-2 is about 510 days, serum IgM antibodies are detected early and increase in the acute phase for 7 days. Specific antibody response can be seen in Figure 8. IgA and IgGspecific antibodies are formed within a few days after IgM and increase in 2-5 weeks and then decrease in 35 weeks after initial symptoms. IgG levels increase 2-7 weeks after initial symptoms and persist for at least 8 weeks. Neutralizing antibodies can block viral progression in vitro which are detectable within $7-15$ days after disease onset and increase up to 14-22 days and then decrease. Low antibody levels are found in asymptomatic and mildly symptomatic patients. 15

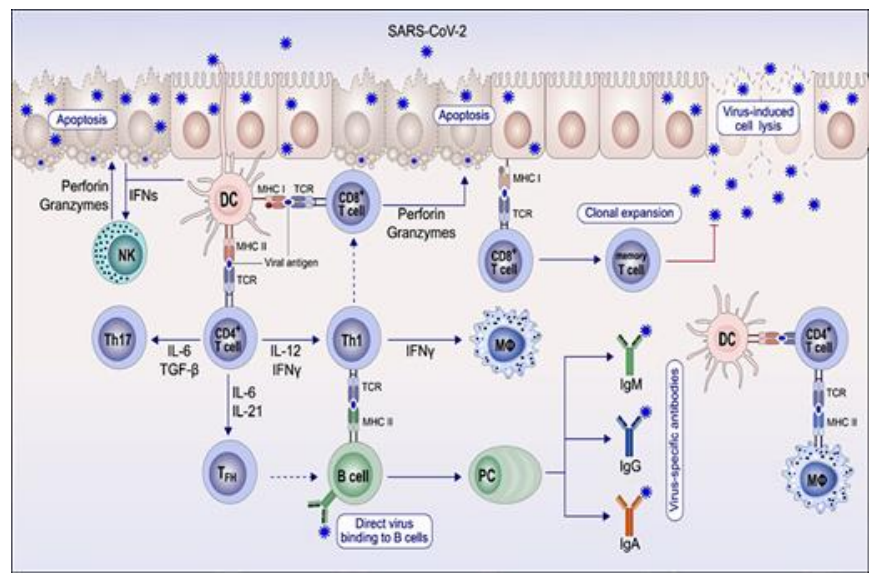

Figure 6. Immune response to SARS CoV-2.15

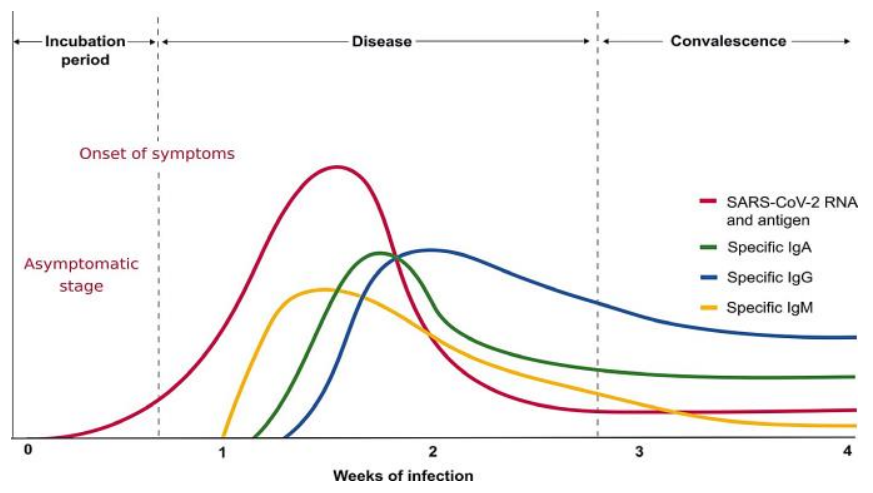

Figure 7. Specific antibody response to SARS CoV-2.15

All COVID-19 vaccine candidates were created to elicit an immune response mediated by neutralizing antibodies (nAbs) against protein S SARS-CoV-2. Protein S helps the attachment of the virus to the ACE2 receptor on the surface of the host cell and initiates fusion between the virus and the cell membrane. Protein $\mathrm{S}$ is in a stable state before contact with host cells and undergoes substantial changes upon fusion with viral cells. Some COVID-19 vaccines work by stabilizing the $\mathrm{S}$ protein in the pre-fusion stage, and there is no attachment to epithelial cells so that it can be protective and reduce transmission. There is RBD in the S1 subunit protein that will bind to the ACE2 receptor. Vaccines work by creating antibodies that bind to RBD to prevent binding and entry of the virus into host cells. 9

Polyclonal antibodies act against multiple epitopes on S protein other than RBD, for example by inhibiting viral attachment, additional neutralizing activity, and/or preventing fusion after attachment. Vaccines that target multiple epitopes can reduce the chance of failure of the immune effect due to mutations. ${ }^{16}$ Lianpai et al. conducted a study to examine the immune response of $\mathrm{T}$ and $\mathrm{B}$ cells on various vaccine platforms. vaccines Whole-virus induce specific IgG against RBD and nAbs but show no $\mathrm{T}$-cell response. Vaccines targeting $\mathrm{S}$ protein induce Th1 cell responses, specific IgG antibodies, nAbs, and IFNy. Vaccines targeting 
protein S subunit 2 exhibit high Th1 cell responses and nAbs. Vaccines targeting RBD induce RBD-specific IgG, nAbs, Th1, and Th2. The immune response in the event of an acute infection is expected to be the same as the immune response that appears during vaccine administration. Immune response involving $\mathrm{T}$ cells and $B$ cells and neutralizing antibodies with specific viruses. The main targets for the COVID-19 virus vaccine are shown in Figure 9.9

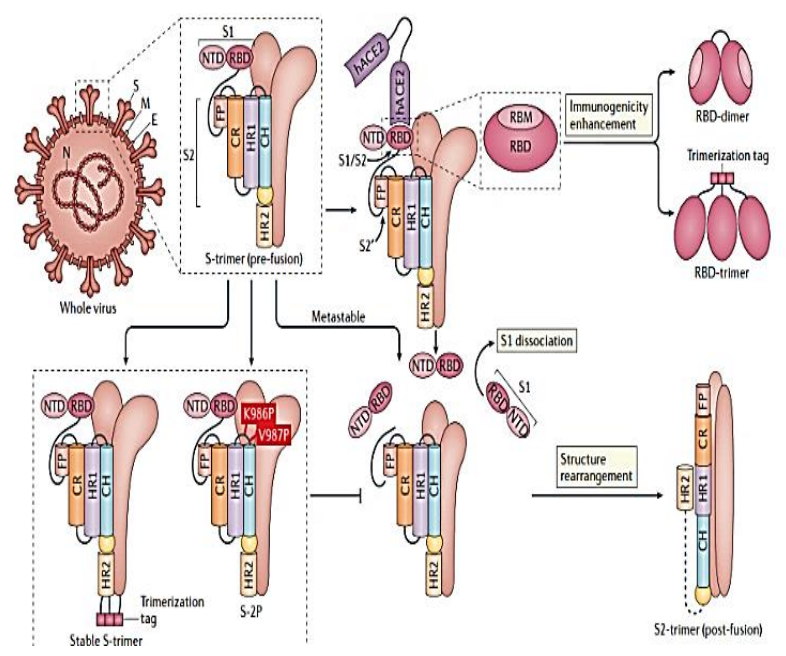

Figure 8 . The main targets for the COVID-19 vaccine. ${ }^{9}$

\section{Vaccine development during the covid-19 vaccine pandemic}

Several vaccines produced to prevent SARS-CoV-2 have been and are being developed around the world. The main factors that must be considered in the process of developing a vaccine are safety, efficacy, and duration of immunity. Vaccine development during a pandemic requires a high production quantity acceleration. 17

\section{Pre-clinical phase}

The principle of developing a new vaccine is its effectiveness against a target population. Experiments using animals that can mimic human disease accurately. The pre-clinical phase aims to determine the response obtained from the vaccine based on several factors, such as interactions between pathogens and host cells, immune protection mechanisms, and the appropriate combination of antigens and adjuvants. The final vaccine design tests before entering clinical trials are toxicity, number of single or repeated doses, immunogenicity, pharmacodynamics (vaccine safety), pharmacokinetics, and local tolerance. 18 The results of this test on animals are used to determine the safe dose range of the vaccine before being tested on humans. If animal trials are successful, vaccine makers and vaccine sponsors must submit an Investigational New Drug (IND) application to the Food and Drug Administration (FDA). 19

\section{Clinical trial phase}

The clinical trial phase is a further 3 phases to assess the safety, immunogenicity, and efficacy of vaccines carried out on healthy participants. Phase I focuses on safety factors, on a small scale using less than 100 healthy subjects. Phase II focuses on the efficacy and range of doses that can provide optimal immunogenicity, and phase III aims to assess whether the dose and time of vaccine administration can have a positive impact on a disease with a good safety profile, using thousands of subjects. ${ }^{18,19}$ Vaccine approval steps and the number of clinical trial subjects can be seen in Figure 10 and Table 1. Vaccine sponsors must report product information related to the efficacy and safety of vaccines after passing phase III through a Biologics License Application (BLA) to the FDA so that an assessment can be carried out. vaccine risks/benefits. The licensed vaccine will then be approved and distributed to the population. The Food and Drug Administration will request sponsors to 
conduct a phase IV study to assess the safety, efficacy, side effects, administration to pregnant women, and further optimal use of the vaccine. 19 The distribution and development stage of the current COVID-19 vaccine can be seen in Figure 11. Several vaccine candidates whose use has been approved are shown in table 3.

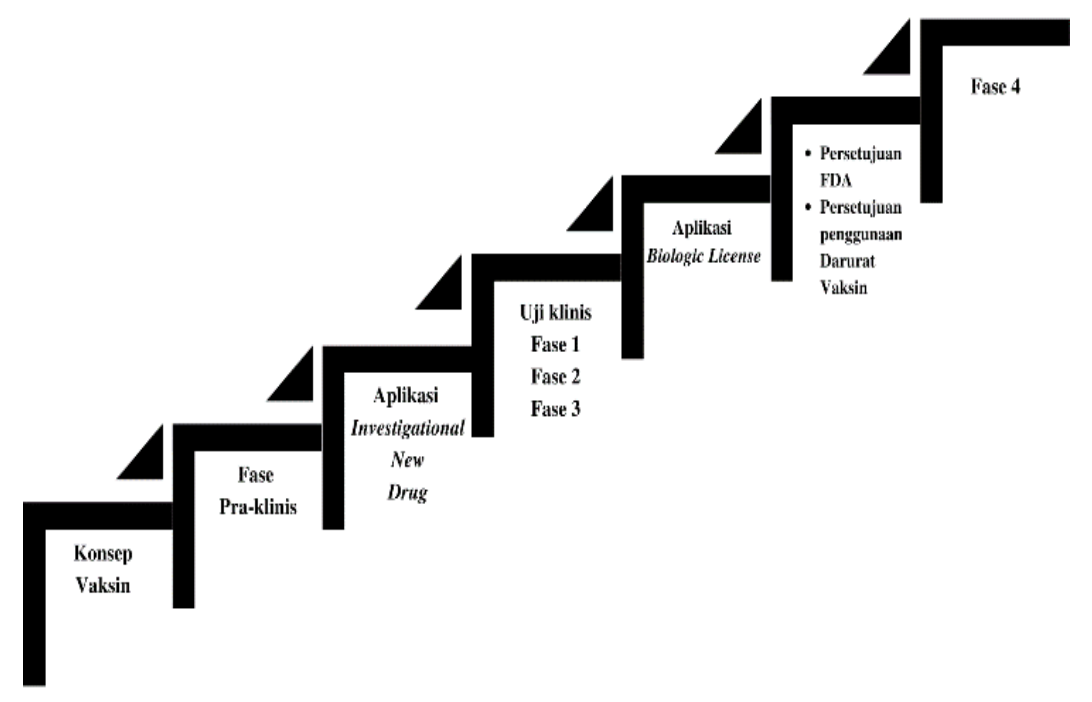

Figure 9. Vaccine approval steps. ${ }^{9}$

Table 1. Clinical phases of vaccines. 20

\begin{tabular}{|c|c|c|}
\hline Phase & Number of Subjects & Information \\
\hline 1 & $10-100$ & $\begin{array}{l}\text { - Test safety and immunogenicity in some low-risk } \\
\text { individuals (healthy young adults) } \\
\text { - Assess vaccine tolerance }\end{array}$ \\
\hline 2 & $100-1000$ & $\begin{array}{l}\text { - Monitor vaccine safety } \\
\text { - Assess potential side effects } \\
\text { - Assess immune response } \\
\text { - Determine optimal dose and schedule of vaccine } \\
\text { administration }\end{array}$ \\
\hline 3 & $1000-10000$ & $\begin{array}{l}\text { - Viewing vaccine efficacy } \\
\text { - Assessing vaccine safety further by involving a } \\
\text { diverse population with a longer duration }\end{array}$ \\
\hline
\end{tabular}

An application for a distribution permit in Indonesia is made after the completion of phase III clinical trials to the Drug Monitoring Agency (BPOM) by completing all the requested requirements. Post-licensing or phase IV clinical trials are carried out after obtaining marketing authorization to monitor and assess any changes in vaccine formulation, use strains, age at immunization, schedule, dose, Post-Immunization Adverse Events (AEFI), concurrent administration of other immunizations, and others.20 Table 2 shows several vaccines that have received Emergency Used Authorization (EUA) in Indonesia. 
Table 2. Vaccines that have received Emergency Used Authorization in Indonesia 21

\begin{tabular}{|c|c|}
\hline Vaccine platforms & Name of vaccine \\
\hline \multirow[t]{3}{*}{$\begin{array}{l}\text { Inactivated } \\
\text { vaccine }\end{array}$} & $\begin{array}{l}\text { Sinovac } \\
\text { (CoronaVac) }\end{array}$ \\
\hline & $\begin{array}{l}\text { Beijing Institute of Biological Products/Sinopharm } \\
\text { (BBIBP-CorV) }\end{array}$ \\
\hline & Covid-19 Bio Farma (from sinovac raw material) Non- \\
\hline \multirow{4}{*}{$\begin{array}{l}\text { viral vector viral } \\
\text { replication }\end{array}$} & (rAd26-S+rAd5-S/Gam-COVID-Vac/Sputnik V) \\
\hline & $\begin{array}{l}\text { Johnson \& Johnson } \\
\text { (Ad26.COV2.S/JNJ-78436735) }\end{array}$ \\
\hline & $\begin{array}{l}\text { University of Oxford/AstraZeneca } \\
\text { (AZD1222; ChAdOx1-S; ChAdOx1 nCoV-19 }\end{array}$ \\
\hline & $\begin{array}{l}\text { CanSino Biological Inc./Beijing Institute of } \\
\text { Biotechnology } \\
\text { (Ad5 nCoV) Confidecia }\end{array}$ \\
\hline \multirow[t]{2}{*}{ mRNA vaccine } & Moderna/NIAID (mRNA-1273) \\
\hline & $\begin{array}{l}\text { BioNTech/Pfizer } \\
\text { (BNT162b1, BNT162b2) Subunit }\end{array}$ \\
\hline \multirow[t]{2}{*}{$\begin{array}{l}\text { Subunit protein } \\
\text { vaccine }\end{array}$} & $\begin{array}{l}\text { Anhui Zhifei Longcom Biopharmaceutical/ } \\
\text { Institute of Microbiology, Chinese Academy of Sciences } \\
\text { (ZF 2001) Zivifax }\end{array}$ \\
\hline & $\begin{array}{l}\text { Serum Institute of India Pvt. Ltd., India (SII) } \\
\text { Novavax (NVX-CoV2373) / Covovax }\end{array}$ \\
\hline
\end{tabular}

The collection and analysis of data required in the evaluation of vaccine risk are:

Cases of disease and cases of AEFI that occurred in a population and within a specified time sure, usually for one year., Data on the severity of AEFIs, morbidity, and mortality caused by AEFIs, Whether a case investigation is carried out to determine which vaccines are available may pose other risks beyond what is already known, Mechanisms and things that may be the cause of the vaccine reaction, How to prevent, predict, and how overcome if an unwanted reaction occurs, Risks associated with using other types of vaccines to protect against the same disease and The risk that occurs if the community population is not immunized is the risk of the emergence of Immunization Preventable Diseases (PD3I) in groups of people who do not immunize.
The summary of the vaccine risk and benefit relationships summarized in tables and diagrams aims to: Assess the relationship between the benefits of vaccination for combating dangerous diseases (PD3I), Deliver messages that are packaged as well as possible about messages that the community needs to know about the benefits of immunization, the efficacy of vaccines in protecting the community and the threat of PD3I expressed in the percentage of the community that can be protected and the safety of the vaccine, Vaccine efficacy and safety should always be disclosed to the public during the implementation of the immunization program, Remind health workers about the possibility of AEFI and Encourage consideration of the use of other types of vaccines with better efficacy and safety. 20 
Table 3. Vaccines approved or currently in phase 3 clinical trials, efficacy, route of administration, dose, and target population 22

\begin{tabular}{|c|c|c|c|c|}
\hline Vaccine platform & $\begin{array}{l}\text { Name of vaccine } \\
\text { Developer }\end{array}$ & Efficacy & $\begin{array}{l}\text { Route of } \\
\text { administratio } \\
\mathrm{n} \\
\text { (dose) }\end{array}$ & $\begin{array}{l}\text { population phase } \\
3 \text { and } 4\end{array}$ \\
\hline \multirow[t]{2}{*}{ mRNA } & $\begin{array}{l}\text { BNT162b2 } \\
\text { Pfizer/BioNTech }\end{array}$ & $95 \%$ & IM (2), & $\begin{array}{l}43,998 \\
\text { (age } 12+\text { ) }\end{array}$ \\
\hline & $\begin{array}{l}\text { mRNA-1273 } \\
\text { Moderna }\end{array}$ & $94.1 \%$ & IM (2), & $\begin{array}{l}0.420 \\
\text { (age } 18+) \\
3,000 \\
(12-<18)\end{array}$ \\
\hline \multirow[t]{4}{*}{$\begin{array}{l}\text { Viral Non- } \\
\text { Replicating } \\
\text { Vector }\end{array}$} & $\begin{array}{l}\text { AZD } 1222 \\
\text { AstraZeneca/ Oxford } \\
\text { University }\end{array}$ & $70.4 \%$ & IM (2), & $\begin{array}{l}12,390 \\
\text { (age } 18+\text { ) }\end{array}$ \\
\hline & $\begin{array}{l}\text { JNJ-78436735 Johnson } \\
\& \\
\text { Johnson }\end{array}$ & $66 \%$ & IM (1), & $\begin{array}{l}44,325 \\
\text { (age } 18+\text { ) }\end{array}$ \\
\hline & $\begin{array}{ll}\text { Convidecia } & \text { CanSino } \\
\text { Biologics } & \\
\end{array}$ & $65.3 \%$ & IM (1), & $\begin{array}{l}40,000 \\
\text { (age 18+) }\end{array}$ \\
\hline & $\begin{array}{lll}\text { Sputnik V Gamaleya } \\
\text { Research } \\
\text { Institute }\end{array}$ & $91.6 \%$ & IM (2), & $\begin{array}{l}33,758 \\
\text { (age } 18+\text { ) }\end{array}$ \\
\hline \multirow[t]{3}{*}{$\begin{array}{l}\text { Inactivation } \\
\text { Vaccine }\end{array}$} & CoronaVac Sinovac & $50.7 \%$ & IM (2), & $\begin{array}{l}12,688 \\
\text { (age } 18+\text { ) }\end{array}$ \\
\hline & BBIBP-CorV Sinopharm & $79.3 \%$ & IM (2), & $\begin{array}{l}3,000 \\
\text { (age 18+) }\end{array}$ \\
\hline & BBV152 Bharat Biotech & $(-)$ & IM (2), & $\begin{array}{l}25,800 \\
\text { (age } 18+\text { ) }\end{array}$ \\
\hline Subunit Vaccine & $\begin{array}{l}\text { Novavax NVX-CoV2373 } \\
\text { Subunit Vaccine }\end{array}$ & $89.7 \%$ & IM (2), & $\begin{array}{l}30,000 \\
\text { (age } 18+\text { ) }\end{array}$ \\
\hline
\end{tabular}

\section{COVID-19 vaccine platform}

Various platforms are being developed where each platform has its advantages and disadvantages. 22
Illustrations of several COVID-19 vaccine strategies can be seen in figures 12 and 14 .

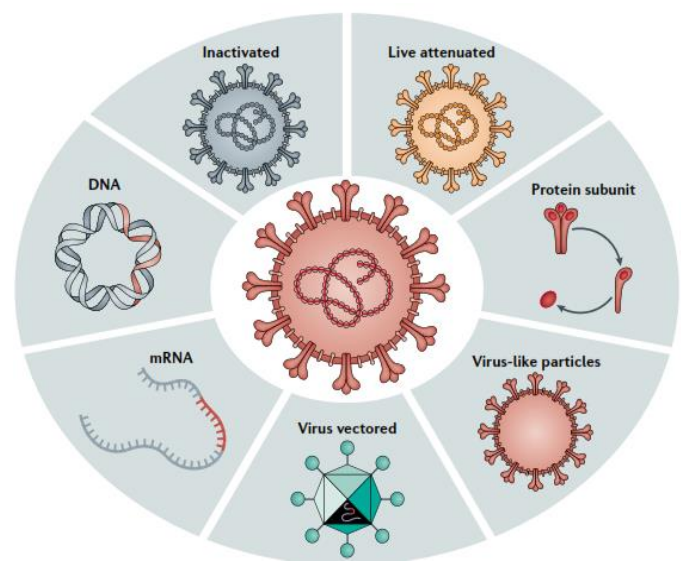

Figure 10. COVID-19 vaccine platform. ${ }^{9}$

\section{Vaccines whole virus conventional}

Conventional whole-virus method vaccines such as inactivated vaccines and live attenuated virus vaccines are the oldest vaccine types and have been used in the development of smallpox, Bacillus Calmette-Guérin (BCG), and measles viruses. All parts of the inactivated or attenuated SARS-CoV-2 virus will be introduced into the body to trigger an immune response. The target of the immune response is not only the $\mathrm{S}$ protein but all parts of the viral protein. vaccines Whole virus require a long production time because breeding large numbers of viruses takes time and requires biosafety level 3 
vaccine candidates whole virus and their clinical stages are shown in table 4.22

\section{Inactivated Vaccines}

Inactivated vaccines are derived from viruses that are developed in a medium and then inactivated using chemicals such as formaldehyde or -propiolactone, heat, or radiation, containing virus-like particles that have lost their pathogenic properties but are still capable of initiating an immune response. This vaccine has been developed against several types of viruses such as hepatitis, polio, and measles. The virus contained in this vaccine cannot replicate so it will not cause infection even if it is given to immunocompromised patients. 22,23

This vaccine cannot induce CD8 T cells adequately but works by activating the Th2 cell-mediated immune response, so this vaccine usually requires additional doses to provide optimal immunity and causes the inactivated vaccine to have a better safety profile. Another disadvantage of this vaccine is that it can lose its ability to trigger an immune response causing low efficacy when compared to live attenuated viruses. Although safer than live attenuated virus vaccines, the immunogenic epitope of the inactivated virus can be damaged during the inactivation process, thereby reducing the desired protective effect.24 There are 26 vaccine candidates, 11 of which are in the pre-clinical phase, 10 vaccines are in the clinical trial phase, and 5 vaccines are in phase 3.22

\section{Attenuated live virus vaccine}

The strategy of attenuating live pathogens as vaccines were first carried out by Pasteur on bacteria in 1880. Vaccines using live attenuated pathogens can mimic the natural infection of the pathogen and replicate without causing severe infection. Some examples of vaccines that have been successfully developed from this strategy include measles, mumps, rubella, and poliomyelitis vaccines. This vaccine can provide a strong immune response. viruses Wild need to mutate to adapt to new host cells and potentially impair their virulence with human cells humans and this requires a long process up to years. Bad processing can cause the virus to revert to the wild genotype. The attenuated virus can bind to the wild, causing the attenuated virus to return to its initial virulence state. Another drawback of the platform is that it cannot be administered to immunocompromised persons because attenuated pathogens can replicate uncontrollably and in some cases may return to the initial phenotypic state and cause severe disease. 22,24

Table 4. Candidate for attenuated virus vaccines and inactivated vaccines. ${ }^{22}$

\begin{tabular}{|c|c|c|c|}
\hline $\begin{array}{l}\text { Vaccine } \\
\text { platform }\end{array}$ & $\begin{array}{l}\text { Developer/Manufacturer } \\
\text { (Vaccine Name) }\end{array}$ & $\begin{array}{l}\text { Clinical } \\
\text { stage }\end{array}$ & $\begin{array}{c}\text { Route of } \\
\text { administration } \\
\text { (Number of doses) }\end{array}$ \\
\hline \multirow[t]{6}{*}{$\begin{array}{l}\text { Inactivated } \\
\text { vaccine }\end{array}$} & $\begin{array}{l}\text { Sinovac } \\
\text { (CoronaVac) }\end{array}$ & Phase 4 & IM $(2)$ \\
\hline & $\begin{array}{lll}\text { Wuhan Institute } & \text { of } & \text { Biological } \\
\text { Products/Sinopharm } & & \\
\end{array}$ & Phase 3 & IM (2) \\
\hline & $\begin{array}{l}\text { Beijing Institute of Biological Products/Sinopharm } \\
\text { (BBIBP-CorV) }\end{array}$ & Phase 3 & IM (2) \\
\hline & Bharat Biotech (Covaxin/BBV152) & Phase 3 & IM (2) \\
\hline & $\begin{array}{l}\text { Institute of Medical Biology, Chinese Academy of } \\
\text { Medical Sciences }\end{array}$ & Phase 3 & IM (2) \\
\hline & Research Institute for Biological Safety Problems & Phase 3 & IM ( 2) \\
\hline $\begin{array}{l}\text { Attenuated live } \\
\text { virus vaccine }\end{array}$ & $\begin{array}{l}\text { Codagenix/Serum Institute of India } \\
\text { (COVI-VAC) }\end{array}$ & Phase 1 & IN (1-2) \\
\hline
\end{tabular}




\section{Vector viral vaccines}

Vector viral vaccines use a non-pathogenic vector to deliver a DNA fragment coded antigen to a host cell using a manufacturing machine cellular proteins, in contrast to conventional vaccines which directly use antigenic proteins to trigger an immune response. Divided into two types, namely viral vector replication and non-replicating viral vectors. Viral vector vaccines can be produced quickly in large quantities and the transportation and storage process does not require too low temperatures, but immunity to pre-formed vectors can limit the vector's ability to deliver antigenic genetic material and can reduce the effectiveness of the vaccine. 22 Several viral vector vaccine candidates and their clinical stages are shown in table 5.

Non-Replicating Viral Vectors

The COVID-19 vaccine in the form of viral vectors was developed by genetic modification of various viral vectors that cannot replicate in the human body such as adenovirus, influenza, measles, ankarapox virus, and vesicular stomatitis virus (VSV). This vaccine is obtained by deleting the structural protein code of the gene in the vector to prevent virion from merging in infected cells. The characteristic of this vaccine is that it can mimic the nature of the virus in expressing antigens to body cells to create humoral and cytotoxic immune responses. The drawback of this vaccine is the presence of immunity that has been formed from the vector used so that it can have an impact on the effectiveness of the vaccine. 22.25

Non-replicating antigens that are included in the vaccine are expected to trigger an immune response. This process creates multiple copies of the vector causing the vector to infect only one cell, delivering the immunogen without causing a viral infection. 23,26 Currently, 12 candidate non-replicating viral vector vaccines are in the clinical trialphase. ${ }^{22}$

\section{Replicating vector virals}

In contrast to non-replicating viral vectors, replicating vector viral vaccines use the potential of vectors to replicate to trigger a persistent immune response in humans. host cells, therefore, vectorreplicated vaccines are administered at low doses. This vaccine cannot be given to immunocompromised because it can cause persistent viral vector pathogenicity, so the use of this vaccine is still in doubt due to the risk and safety profile of the vaccine. ${ }^{23}$ There are currently 6 vaccine candidates in the clinical trial phase. 22

\section{Nucleic acid-based vaccines}

Nucleic acid-based vaccines deliver genetic code DNA or messenger RiboNucleic Acid (mRNA) antigens to host cells to trigger immunogens as illustrated in figure 13. In situ foreign immunogens in host cells can activate antibody production and induce $\mathrm{T}$ cells. Nucleic acid-based vaccines can be produced in large quantities more easily. ${ }^{2}$ Some candidate nucleic acidbased vaccines and their clinical stages are shown in table 6 .

\section{DNA Vaccines}

DNA vaccines use a DNA plasmid containing a mammalian expression promoter and a transgene that encodes an antigenic protein, such as protein S. 
Table 5. Subunit protein vaccine candidates and virus-like particle vaccines. ${ }^{22}$

\begin{tabular}{|c|c|c|c|}
\hline Vaccine platform & $\begin{array}{l}\text { Developer/Manufacturer } \\
\text { (Name of vaccine) }\end{array}$ & Clinical stage & $\begin{array}{c}\text { Route of } \\
\text { administration } \\
\text { (Number of Doses) }\end{array}$ \\
\hline \multirow[t]{7}{*}{$\begin{array}{l}\text { Non-Replicating } \\
\text { Virus Vectors }\end{array}$} & $\begin{array}{l}\text { University of Oxford/AstraZeneca } \\
\text { (AZD1222; ChAdOx1-S; ChAdOx1 nCoV-19) }\end{array}$ & Phase 4 & IM $(1-2)$ \\
\hline & $\begin{array}{l}\text { CanSino Biological Inc./Beijing Institute of } \\
\text { Biotechnology } \\
\text { (Ad5 } \mathrm{nCoV)}\end{array}$ & Phase 3 & IM (1) \\
\hline & $\begin{array}{l}\text { Gamaleya Research Institute } \\
\text { (rAd26-S+rAd5-S/Gam-COVID-Vac/Sputnik V) }\end{array}$ & Phase 3 & IM (2) \\
\hline & $\begin{array}{l}\text { Johnson \& Johnson } \\
\text { (Ad26.COV2.S/JNJ-78436735) }\end{array}$ & Phase 3 & $\mathrm{IM}(1-2)$ \\
\hline & $\begin{array}{l}\text { ImmunityBio, Inc. \& NantKwest Inc. } \\
\text { (hAd5-COVID-19/hAd5-S-Fusion+N-ETSD) }\end{array}$ & Phase 1 & Oral (1) \\
\hline & $\begin{array}{l}\text { ReiThera/LEUKOCAR } \\
\text { (Gard-CoV2) }\end{array}$ & Phase 1 & IM (1) \\
\hline & City of Hope (COH04S1) & Phase 1 & IM (1-2) \\
\hline \multirow[t]{3}{*}{$\begin{array}{c}\text { Viral Vector } \\
\text { Replication Vaccine }\end{array}$} & $\begin{array}{l}\text { Jiangsu Provincial Center for Disease } \\
\text { Prevention and Control } \\
\text { (DelNS1-2019-nCoV-RBD-OPT1 (Intranasal flu- } \\
\text { based RBD) }\end{array}$ & Phase 2 & IN (1) \\
\hline & $\begin{array}{l}\text { Shenzhen Geno-Immune Medical Institute } \\
\text { (Covid-19/aAPC vaccine) }\end{array}$ & Phase 1 & $\mathrm{SC}(3)$ \\
\hline & $\begin{array}{l}\text { Israel Institute for Biological Research/ } \\
\text { Weizmann Inst. of Science } \\
\text { (VSV-S) }\end{array}$ & Phase $1 / 2$ & IM (1) \\
\hline
\end{tabular}

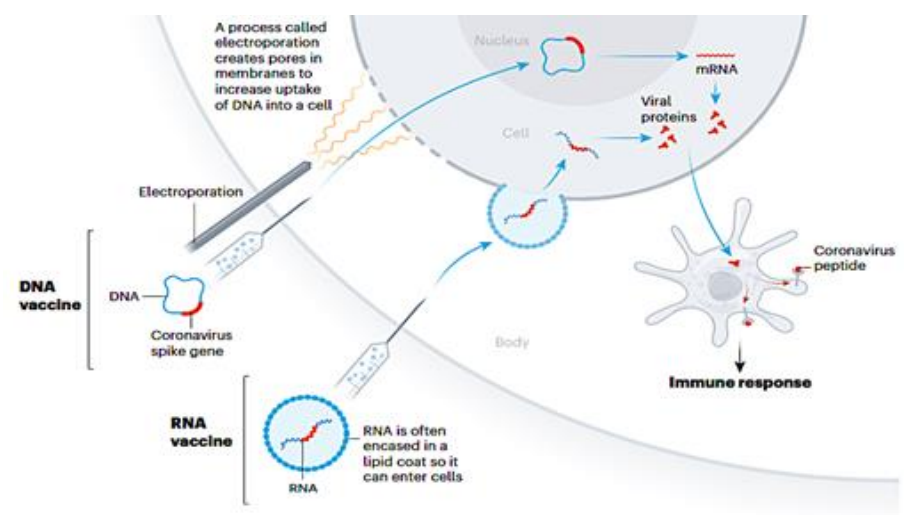

Figure 11. Nucleic acid-based vaccines. 27

This strategy can be adapted for the formation of other vaccines with different antigens. The effectiveness of the vaccine will be reduced if it is given by traditional injection, without adjuvants, and without special equipment. The optimal administration of vaccines is to use the intradermal short-circuit electric shock method using special tools, namely electroporators so that the vaccine can penetrate the cell membrane temporarily and reversibly which causes large molecules such as plasmids to enter the cell membrane. The viral nucleotide chain strand is changed by replacing optimal codons with non-optimal codons to increase the specific immune response mediated by CD8 T cells. The advantages of this vaccine are that it is noninfectious, short production time is cheap, stable, and this vaccine is easy to produce in vitro and stable at room temperature so that this simplifies the process of storing and delivering vaccines. To date, no DNA vaccine has been approved.22,26,28

\section{mRNA vaccines}

The concept of creating mRNA vaccines has been 
found since the early 21 st century. mRNA vaccines work by imitating the genetic code of pathogens, messenger RNA will be translated by host cells as a pathogenic protein, this vaccine provides a blueprint for cells to create a protein. Cell host will elicit an immune response by producing appropriate antibodies against foreign proteins that are translated according to the pathogen introduced through the vaccine. ${ }^{29}$

The mRNA vaccine has several advantages over other traditional vaccines, namely the development and production process can be carried out in a short time, is inexpensive, and has a good efficacy and safety profile. The vaccine will be inserted into muscle cells, moved to the cytosol, then the ribosomes will translate the virus $\mathrm{S}$ protein, which when released into the circulatory system will activate the immune system response. 30

Lipid nanoparticles are one way to overcome the instability of mRNA vaccines and act as adjuvants and trigger B-cell and T-follicular immune responses. Lipid nanoparticles from the vaccine will enter myocytes by endocytosis. mRNA is then released into the cytoplasm and will code for the $\mathrm{S}$. protein in the ribosome so that $\mathrm{S}$ protein can be formed. S. protein can then break down into peptides or leave the cell. Peptides that are in the cell will enter into (MHC) class I molecules. S. protein that has left the previous cell will enter the dendritic cell through endocytosis and be degraded in the endosome into MHC class II molecules. S. protein can also be presented to MHC I via cross-presentation on dendritic cells. MHC I will induce CD8 T cells while MHC II will induce CD4 T cells. CD8. T cell activation will lead to the formation of a system immunity T-cellmediated antigen-specific cytotoxic. Second This immune complex then destroys the S. protein and mRNA from the vaccine through the formation of antibodies, so that an adaptive immune system will be formed against SARS-CoV-2.31

mRNA-based vaccines include, the risk of infection during the vaccine production period is low, experiments on mice have shown that repeated vaccine administration provides long-term immunity, and there is no possibility of insertion of mutations in cells because viral antigens do not enter the cell nucleus. The mRNA vaccine has been used as a preventive against several diseases such as Ebola, Respiratory Syncytial Virus (RSV), human immunodeficiency virus (HIV), and influenza virus. 28 There are 2 mRNA vaccines approved for use in various countries and 6 other candidates are still in the clinical trial stage.

\section{Recombinant viral protein-based}

Vaccine Virus protein-based vaccines are created using recombinant technology where this vaccine only contains viral proteins (immunogens), does not use the whole virus so there is no genetic material in it, therefore this vaccine has a better safety profile than vaccine whole virus. 22 Some candidate vaccines based on recombinant protein are shown in table 7 .

\section{Subunit protein vaccine}

Subunit protein vaccines were developed from recombinant protein antigen synthesis, protein isolation, and purification methods after culturing large quantities of pathogens. Most vaccines use protein S or RBD as antigens. Creating a full length is difficult because the $\mathrm{S}$ protein binds to a membrane consisting of several subunits. The use of RBD as an antigen can also trigger neutralizing antibodies and is easier to create, however, the epitope contained in RBD is not as complete as the epitope found in full-length, therefore the effectiveness of length will be better than vaccines based on RBD.22 Subunit protein vaccines require booster and optimization of adjuvant drugs to achieve strong immunity. ${ }^{24}$ The effect of this vaccine is highly dependent on the adjuvant due to the unstable nature of the peptide so it must be incorporated into the nanoparticles that are absorbed into the adjuvant. 28 Lack of this vaccine is difficult to produce in large quantities, it requires the use of adjuvants and repeated doses to get a strong immune effect.9.25 Currently, 24 subunit protein vaccines have entered the clinical trial phase and another 64 candidates are still in the pre-clinical stage. 22 
Table 6. DNA vaccine candidates and RNA vaccines. ${ }^{22}$

\begin{tabular}{|c|c|c|c|}
\hline $\begin{array}{l}\text { Vaccine } \\
\text { platform }\end{array}$ & $\begin{array}{l}\text { Developer/Manufacturer } \\
\text { (Name of vaccine) }\end{array}$ & $\begin{array}{l}\text { Clinical } \\
\text { stage }\end{array}$ & $\begin{array}{c}\text { Route of } \\
\text { administration } \\
\text { (Number of Doses) }\end{array}$ \\
\hline \multirow[t]{7}{*}{ DNA } & $\begin{array}{l}\text { Inovio Pharmaceuticals/International Vaccine } \\
\text { Institute } \\
\text { (INO-4800) }\end{array}$ & Phase $2 / 3$ & ID (2) \\
\hline & $\begin{array}{l}\text { Osaka University/AnGes/Takara Bio } \\
\text { (AG0301 COVID19, AG0302 COVID19) }\end{array}$ & Phase $2 / 3$ & IM (2) \\
\hline & $\begin{array}{l}\text { Cadila Healthcare Limited } \\
(Z y C o V-D)\end{array}$ & Phase 1 & ID (3) \\
\hline & Genexine Consortium (GX-19) & Phase $1 / 2$ & IM (2) \\
\hline & $\begin{array}{l}\text { Symvivo } \\
\text { (bacTRL-Spike) }\end{array}$ & Phase 1 & Oral (1) \\
\hline & $\begin{array}{l}\text { Providence Health \& Services } \\
\text { (CORVax) }\end{array}$ & Phase 1 & ID (2) \\
\hline & Entos Pharmaceuticals Inc. (Covigenix VAX-001) & Phase 1 & IM (2) \\
\hline \multirow[t]{8}{*}{ RNA } & Moderna/NIAID (mRNA-1273) & Phase 4 & IM (2) \\
\hline & $\begin{array}{l}\text { BioNTech/Pfizer } \\
\text { (BNT162b1, BNT162b2) }\end{array}$ & Phase 4 & IM (2) \\
\hline & $\begin{array}{l}\text { Curevac } \\
\text { (CVNCOV) }\end{array}$ & Phase 3 & IM (2) \\
\hline & Arcturus/Duke-NUS (ARCT-021) & Phase 2 & $(-)$ \\
\hline & $\begin{array}{l}\text { Imperial College London } \\
\text { (LNP-nCoVsaRNA) }\end{array}$ & Phase 1 & IM (2) \\
\hline & $\begin{array}{l}\text { Shulan Hospital/Center for Disease Control and } \\
\text { Prevention of Guangxi Zhuang Autonomous Region } \\
\text { (SARS-CoV-2 mRNA vaccine) }\end{array}$ & Phase 1 & IM (2) \\
\hline & Chulalongkorn University (ChulaCov19) & Phase 1 & IM (2) \\
\hline & $\begin{array}{l}\text { Providence Therapeutics } \\
\text { (PTX-COVID19-B) }\end{array}$ & Phase 1 & IM (2) \\
\hline
\end{tabular}


Table 7 . Subunit protein vaccine candidates and virus-like particle vaccines.22

\begin{tabular}{|c|c|c|c|}
\hline Vaccine platform & $\begin{array}{l}\text { Developer/Manufacturer } \\
\text { (Name of vaccine) }\end{array}$ & $\begin{array}{l}\text { Clinical } \\
\text { stage }\end{array}$ & $\begin{array}{c}\text { Route of } \\
\text { administration } \\
\text { (Number of } \\
\text { Doses) }\end{array}$ \\
\hline \multirow[t]{24}{*}{ Protein Subunit } & Novavax (NVX-CoV2373) & Phase 3 & IM (2) \\
\hline & $\begin{array}{l}\text { Anhui Zhifei Longcom } \\
\text { Biopharmaceutical/ } \\
\text { Institute of Microbiology, Chinese } \\
\text { Academy of Sciences } \\
\text { (ZF 2001) }\end{array}$ & Phase 3 & $\mathrm{IM}(2 / 3)$ \\
\hline & $\begin{array}{l}\text { Kentucky Bioprocessing, Inc. (KBP- } \\
\text { COVID-19/KBP-201) }\end{array}$ & Phase $1 / 2$ & IM (2) \\
\hline & Sanofi Pasteur & Phase $1 / 2$ & IM (2) \\
\hline & Biological E Ltd. & Phase $1 / 2$ & IM (2) \\
\hline & $\begin{array}{l}\text { West China Hospital, Sichuan } \\
\text { University }\end{array}$ & Phase 2 & IM (2) \\
\hline & $\begin{array}{l}\text { Clover Biopharmaceuticals Inc. ( SCB- } \\
\text { 2019) }\end{array}$ & Phase $2 / 3$ & IM (2) \\
\hline & Vaxine Pty Ltd. (COVAX-19) & Phase 1 & IM (1) \\
\hline & $\begin{array}{l}\text { Medigen Vaccine Biologics Corporation } \\
\text { (MVC-COV1901) }\end{array}$ & Phase 2 & IM (2) \\
\hline & $\begin{array}{l}\text { Center for Genetic Engineering and } \\
\text { Biotechnology (Soberana 01) }\end{array}$ & Phase $1 / 2$ & IM (3) \\
\hline & $\begin{array}{l}\text { Center for Genetic Engineering and } \\
\text { Biotechnology } \\
\text { (Soberana 02) }\end{array}$ & Phase $1 / 2$ & IM (3) \\
\hline & $\begin{array}{l}\text { FBRI SRC VB VECTOR, } \\
\text { Rospotrebnadzor, } \\
\text { Koltsovo }\end{array}$ & Phase $1 / 2$ & IM (2) \\
\hline & $\begin{array}{l}\text { University Hospital Tuebingen } \\
\text { (CoVAC-1) }\end{array}$ & Phase 1 & $\mathrm{SC}(1)$ \\
\hline & COVAXX (UB-612) & Phase $2 / 3$ & $\mathrm{IM}(2)$ \\
\hline & Adimmune Corporation & Phase 1 & - \\
\hline & $\begin{array}{l}\text { Nanogen Pharmaceutical } \\
\text { Biotechnology }\end{array}$ & Phase $1 / 2$ & IM (2) \\
\hline & Shionogi Inc. (S268019) & Phase $1 / 2$ & IM (2) \\
\hline & $\begin{array}{l}\text { Instituto Finlay de Vacunas (FINLAY- } \\
\text { FR1) }\end{array}$ & Phase $1 / 2$ & IM (2) \\
\hline & $\begin{array}{l}\text { Instituto Finlay de Vacunas (FINLAY- } \\
\text { FR2) }\end{array}$ & Phase 2 & IM (2) \\
\hline & $\begin{array}{l}\text { University Medical Center Groningen + } \\
\text { Akston Biosciences Inc. (SARS-CoV-2- } \\
\text { RBD-Fc fusion protein) }\end{array}$ & Phase $1 / 2$ & SC/IM (-) \\
\hline & $\begin{array}{l}\text { University of Saskatchewan (COVAC-1 } \\
\text { and COVAC- } 2 \\
\text { subunit vaccine (spike protein)) }\end{array}$ & Phase $1 / 2$ & IM (2) \\
\hline & SK Bioscience Co., Ltd. (GBP510) & Phase $1 / 2$ & IM (2) \\
\hline & $\begin{array}{l}\text { Razi Vaccine and Serum Research } \\
\text { Institute (Razi Cov Pars, recombinant } \\
\text { spike protein) }\end{array}$ & Phase 1 & IM/IN (3) \\
\hline & $\begin{array}{l}\text { The University of Queensland (MF59 } \\
\text { adjuvanted SARS-CoV-2 Sclamp } \\
\text { vaccine) }\end{array}$ & Phase 1 & IM (2) \\
\hline \multirow{2}{*}{$\begin{array}{l}\text { Vaksin Virus- } \\
\text { Like Particle }\end{array}$} & Medicago Inc. & Phase $2 / 3$ & IM (2) \\
\hline & SpyBiotech/Serum Institute of India & Phase $1 / 2$ & $\mathrm{IM}(2)$ \\
\hline
\end{tabular}




\section{Vaccines virus-like particle}

This vaccine uses an empty viral particle that has a copy of the SARS-CoV-2 antigen on its surface, forming a particle consisting of several antigenic protein structures that are expressed together. The manufacture of vaccines imitates the structure of the virus which is expected to be able to trigger an immune response against the antigens on its surface. S protein expressed on the surface of VLP can cause binding and enter ACE2 like the native antigen, bind to $\mathrm{B}$ cell receptors, and activate $B$ cells. Vaccination can be administered subcutaneously, mucosal, and inhalation. This vaccine has a good safety profile due to the lack of information on the genetic material of the pathogen. ${ }^{24}$ There are currently two vaccine candidates in the clinical trial phase. ${ }^{22}$

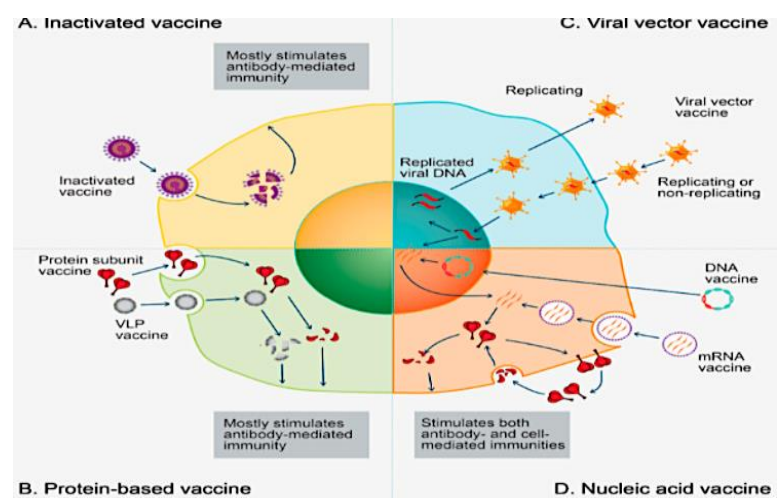

Figure 12. platforms and methods of producing immunogens in cells. ${ }^{22}$

Table 8 . The advantages and disadvantages of each vaccine strategy.22,37

\begin{tabular}{|c|c|c|}
\hline Vaccine Platform & Advantages & Disadvantages \\
\hline DNA & $\begin{array}{l}\text { - } \text { Does not contain infectious material } \\
\text { - } \quad \text { Can be given to immunocompromised patients } \\
\text { - } \quad \text { Long-lasting immune response } \\
\text { - Stable } \\
\text { - } \quad \text { Possibility of oral administration } \\
\text { - } \quad \text { Stable at room temperature }\end{array}$ & $\begin{array}{l}\text { - No approved DNA-based vaccines } \\
\text { - Mucosal and other immunity Variable } \\
\text { - Requires specialized equipment for intradermal } \\
\text { administration } \\
\text { - Has the risk of integration with host cell }\end{array}$ \\
\hline RNA & $\begin{array}{l}\text { - } \text { Production can be carried out in a short time } \\
\text { - } \quad \text { No risk of integration into the genome } \\
\text { - } \text { Contains no infectious material } \\
\text { - } \quad \text { No potential for mutagenesis } \\
\text { - } \quad \text { Strong T cell response } \\
\text { - } \quad \text { Can be produced globally }\end{array}$ & $\begin{array}{l}\text { - No approved RNA vaccine } \\
\text { - } \quad \text { Possible Inflammatory reactions may occur } \\
\text { - Most formulations require the frozen chain to } \\
\text { be durable and stable. } \\
\text { - Requires booster for strong immune effect. }\end{array}$ \\
\hline Protein Subunit & $\begin{array}{l}\text { - } \quad \text { Contains no infectious material } \\
\text { - } \quad \text { Tarong antibody response. } \\
\text { - } \quad \text { protein complexes can be formulated as a } \\
\text { stimulus to form virus-like particles }\end{array}$ & $\begin{array}{l}\text { - } \\
\text { - } \\
\text { Difficult to produce in large quantities } \\
\text { Potential to lose protective glycan from native } \\
\text { viruses }\end{array}$ \\
\hline Viral vectors & $\begin{array}{l}\text { - Safety profile and the resulting immune response } \\
\text { have been studied for many years } \\
\text { - Strong cellular antibody response } \\
\text { - } \quad \text { Rapid production } \\
\text { - Can be dosed low/single dose }\end{array}$ & $\begin{array}{l}\text { - Risk of chromosomal integration with } \\
\text { oncogenesis } \\
\text { - } \quad \text { Cannot be administered to immunocompromised } \\
\text { - } \quad \text { Inflammatory AEs may occur Variable } \\
\text { - } \quad \text { Dimmunogenicity } \\
\text { - } \quad \text { Has immunity to previous vectors }\end{array}$ \\
\hline Live attenuated virus & $\begin{array}{ll} & \text { Proven technology } \\
\text { - } & \text { Provides a strong and durable immune response } \\
\text { - } & \text { Multivalent } \\
\text { - } & \text { Formulation simple, no need for adjuvants } \\
\text { - } & \text { Can be produced in large quantities }\end{array}$ & $\begin{array}{l}\text { - } \quad \text { Requires biosafety special } \\
\text { viruses are at risk of returning to their initial } \\
\text { virulence state }\end{array}$ \\
\hline Virus inactivation & $\begin{array}{l}\text { - } \\
\text { - }\end{array}$ & $\begin{array}{ll} & \text { Requires biosafety specialized } \\
\text { - } & \text { Difficult to produce in large quantities } \\
\text { - } & \text { Low purity level }\end{array}$ \\
\hline Virus-like particle & $\begin{array}{l}\text { - Contains no infectious material } \\
\text { - Broad antigenic }\end{array}$ & $\begin{array}{ll} & \text { profile Limited immunogenicity } \\
\text { - } & \text { Low purity level }\end{array}$ \\
\hline
\end{tabular}


Adjuvants in COVID-19 vaccine

Adjuvants affect prophylactic and therapeutic efficacy vaccines by reducing the number of antigens required to elicit a long-lasting immune response, triggering inflammatory cytokines and chemokines, as well as Th1 and Th2 cell responses, triggering the innate immune system through Toll-like receptors. The protein subunit vaccine is the most widely used adjuvant vaccine. Some of the adjuvants used in most vaccines are shown in table 9. Many other natural products are being investigated for use as adjuvants such as polysaccharides, interferons, -galactoscleramid
(GM-CSF), and synthetic compounds (saponin derivatives). Most of the adjuvants listed in Table 8 target the PRR system of innate immunity. Pattern Recognition Receptor will detect PAMPs and become hosts of DAMPs via inflammatory receptors, Stimulator of Interferon Genes Protein (STING), and TLR.22

\section{Nano-particle-based vaccine delivery devices}

Nanotechnology as a vaccine and adjuvant delivery device has developed very rapidly. Efficient vaccine delivery can provide the full therapeutic potential of mRNA vaccines.

Table 9. Adjuvants to vaccines. 22

\begin{tabular}{|c|c|}
\hline $\begin{array}{c}\text { Adjuvant } \\
\text { (Trade names) }\end{array}$ & $\begin{array}{c}\text { Vaccine } \\
\text { (Indication) }\end{array}$ \\
\hline aluminum hydroxide (Alhydrogel) & $\begin{array}{l}\text { Infanrix (DTP) } \\
\text { Havrix (hepatitis A) }\end{array}$ \\
\hline aluminum phosphate (AdjuPhos) & $\begin{array}{l}\text { Tenivac (tetanus, diphtheria) } \\
\text { UB-612 (COVID-19) }\end{array}$ \\
\hline aluminum hydroxyphosphate sulfate & $\begin{array}{l}\text { PedvaxHIB (Haemophilus)Gardasil } \\
\text { (HPV) }\end{array}$ \\
\hline $\begin{array}{l}\text { Water-oil emulsion squalene } \\
\text { (MF59) }\end{array}$ & Fluad (influenza) \\
\hline $\begin{array}{l}\text { monophosphoryl lipid A dan QS-21 saponin } \\
\text { (AS01b) }\end{array}$ & Shingrix (herpes zoster) \\
\hline $\begin{array}{l}\text { squalene/a-tocopherol/Tween } 80 \\
\text { (ASO3) mix }\end{array}$ & $\begin{array}{l}\text { Pandemrix (influenza) } \\
\text { SCB-2019 (COVID-19) }\end{array}$ \\
\hline $\begin{array}{l}\text { Water-oil emulsion squalene } \\
\text { (AF03) }\end{array}$ & Humenza (influenza) \\
\hline $\begin{array}{l}\text { Campuran saponins } \\
\text { (Matrix M) }\end{array}$ & NVX-CoV2373 (COVID-19) \\
\hline $\begin{array}{l}\text { monophosphoryl lipid } A+\text { aluminum hydroxide } \\
\text { (AS04) }\end{array}$ & Cervarix (HPV) \\
\hline $\begin{array}{l}\text { glucopyranosyl lipid A } \\
\text { (GLA-SE) }\end{array}$ & ID93 (tuberculosis) \\
\hline $\begin{array}{l}\text { phosphorothioate oligodeoxyribonucleotide } \\
\text { (CpG 1018) }\end{array}$ & $\begin{array}{l}\text { Heplisav-B (hepatitis B) } \\
\text { SCB-2019 (COVID-19) } \\
\text { MVC-COV1901 (COVID-19) }\end{array}$ \\
\hline $\begin{array}{l}\text { inulin } \\
\text { (Advax) }\end{array}$ & COVAX-19 (COVID-19) \\
\hline $\begin{array}{l}\text { potassium aluminum sulfate } \\
\text { (Alum) }\end{array}$ & - \\
\hline $\begin{array}{l}\text { imidazoquinoline derivatives } \\
(3 \mathrm{M}-052)\end{array}$ & (HIV, tumor) \\
\hline $\begin{array}{l}\text { Water-oil emulsion squalane sucrose fatty acid sulfate ester (CoVaccine } \\
\text { HT) }\end{array}$ & CiVax (COVID-19) \\
\hline $\begin{array}{l}\text { Water-oil emulsion mannide monooleate surfactant Montanide } \\
\text { (ISA-51) }\end{array}$ & $\begin{array}{l}\text { Galinpepimut-S (mesothelioma) } \\
\text { SurVaxM (neuroendocrine tumor) }\end{array}$ \\
\hline
\end{tabular}


Several physicochemical compounds in nucleic acids such as negative pressure and hydrophilicity can inhibit the passive diffusion of vaccines to the plasma membrane. Several barriers in the form of binding to serum proteins, the process of phagocytosis, and the process of degradation by endogenous nucleases can reduce the efficiency of nucleic acid delivery to the target, therefore a conductor is needed to prevent degradation. 22

The mRNA vaccine developed by Pfizer/BioNTech and Moderna uses lipid nanoparticles as a carrier with a formulation of ionizable cationic lipids. Lipid nanoparticles consist of synthetic cationic lipids that form nanoscale complexes and polyanionic nucleic acids. Enveloped by positively charged lipids, mRNA becomes more stable and less susceptible to RNase degradation. Lipid nanoparticles will exit the endosol after endocytosis, delivering nucleic acids to the cytosol where mRNA is translated into antigenic proteins, so that the immune system will produce antibodies. The basic steps of nucleic acid delivery are the uptake and endocytosis of lipid nanoparticles in the cell and the release of nucleic acids. The composition of lipid nanoparticles used in Pfizer/BioNTech and Moderna vaccines is similar, namely ionized cation lipids, Polyethylene Glycol (PEG), cholesterol, and lipids Distearoylphosphatidylcholine (DSPC) lipids which act as lipid helpers as shown in Figure 15. Some of the lipid nanoparticles used in the two approved mRNA vaccines are shown in Table 10.22

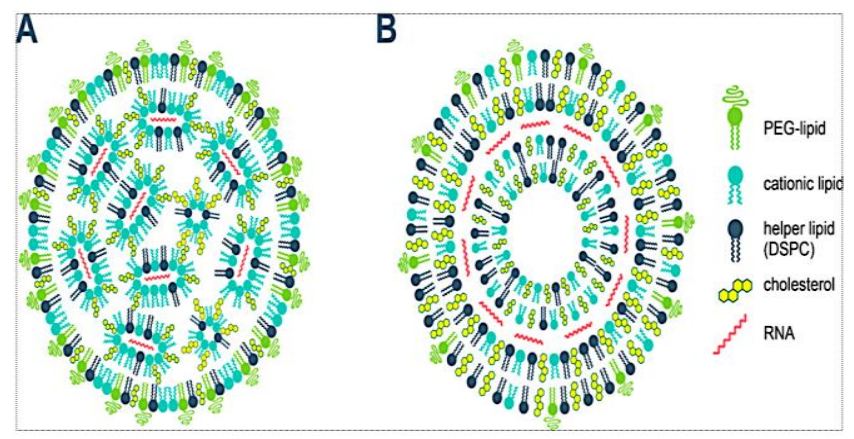

Figure 13. Structure of lipid nanoparticles as vaccine carriers. 22

Table 10. Lipid nanoparticles in mRNA vaccines. 22

\begin{tabular}{|l|c|}
\hline \multicolumn{1}{|c|}{ Lipid Name } & Abbreviation/lab code \\
\hline \multicolumn{2}{|c|}{ Pfizer/BioNTech } \\
\hline $\begin{array}{l}\text { ((4-hydroxybutyl) azanediyl) bis(hexane6,1- } \\
\text { diyl) } \\
\text { bis(2-hexyldecanoate) }\end{array}$ & ALC-0315 \\
\hline $\begin{array}{l}\text { 2-[(polyethylene glycol)-2000]- } \\
\text { N,Nditetradecylacetamide }\end{array}$ & ALC-0159 \\
\hline $\begin{array}{l}\text { 1,2-distearoyl-sn-glycero-3-phosphocholine } \\
\text { cholesterol }\end{array}$ & SM-102 \\
\hline \multicolumn{1}{|c|}{ Moderna } \\
\hline $\begin{array}{l}\text { heptadecan-9-yl 8- ((2 hydroxyethyl) (6oxo-6- } \\
\text { (undecyloxy) hexyl amino) } \\
\text { octanoate }\end{array}$ \\
\hline $\begin{array}{l}\text { 1,2-dimyristoyl-rac-glycero- } \\
\text { 3methoxypolyethylene } \\
\text { glycol 2000 }\end{array}$ \\
\hline $\begin{array}{l}\text { 1,2-distearoyl-sn-glycero-3-phosphocholine } \\
\text { cholesterol }\end{array}$ \\
\hline
\end{tabular}




\section{Causes of vaccine allergy reactions}

Allergic reactions to vaccines are rarely caused by the vaccine itself but are mostly caused by additives such as egg protein, gelatin, formaldehyde, thimerosal, and neomycin. The additives aim to increase the solubility and absorption of the vaccine, trigger a stronger immune response, and stabilize the vaccine during delivery and storage. Mild to severe allergic reactions can be caused by additives, ranging from symptoms of itchy skin to severe systemic reactions that can be life-threatening. ${ }^{32}$

Polyethylene Glycol and polysorbate are additives used in most vaccines, causing most allergies, used to increase water solubility and stabilization of nanoparticles in nucleic acid-based vaccines. Immunoglobulin $\mathrm{M}$ and Immunoglobulin $\mathrm{G}$ can trigger a Complement Activation-Related PseudoAllergy (CARPA) non-specific immune response to PEG-containing vaccines such as Pfizer/BioNTech and Moderna. Polysorbate is structurally similar to PEG, contains polyethers, and can cross-react with PEG. Several cases of allergy were reported after patients received vaccines containing polysorbate such as Astrazeneca. ${ }^{32}$

\section{Transportation and storage of vaccines}

Vaccines must be stored and shipped properly to prevent vaccine-preventable diseases. Errors in storage and delivery can result in financial loss, revaccination, and reduce public confidence in vaccines. All vaccines are thermo-sensitive, so vaccines must be stored and distributed under optimal conditions in a controlled temperature environment known as the vaccine cold chain. Vaccine effectiveness can be compromised if exposed to conditions that are not following vaccine handling standards such as exposure to heat, cold, or excessive light. The vaccine cold chain begins with factory vaccine storage at the place of manufacture, transportation, and delivery, to administering vaccines to patients. ${ }^{33}$
The success vaccine cold chain depends on 3 things: trained staff, good storage, and monitoring tools, and accurate vaccine inventory management. Staff who receive and deliver vaccines must be well trained and familiar with Standard Operating Procedures (SOPs) for vaccine storage and delivery to ensure vaccine potency and patient safety. 33

Every health care place must have good storage and monitoring tools. Recommended devices have a pharmaceutical grade for vaccine storage and temperature monitoring. Periodic temperature checks are carried out at the beginning of shipment, when the container is opened, and at the end of the shipment. Before use, the vaccine refrigerator must be at a temperature between $2^{\circ} \mathrm{C}$ and $8{ }^{\circ} \mathrm{C}\left(366^{\circ} \mathrm{F}\right.$ and $46^{\circ} \mathrm{F}$ ) while the freezer must be at $-50^{\circ} \mathrm{C}$ and $-15^{\circ} \mathrm{C}$ $\left(-58^{\circ} \mathrm{F}\right.$ and $\left.5^{\circ} \mathrm{F}\right)$ to prevent temperature changes at the beginning of storage. Accurate inventory management is needed to avoid financial losses due to high vaccine prices, so the process of ordering, shipping, storing, and administering vaccines to patients must be carried out according to standard operating procedures. 33

Transportation Pfizer-BioNTech vaccine using a temperature monitoring device in a portable ultra-cold freezer between $-90^{\circ} \mathrm{C}$ and $-60^{\circ} \mathrm{C}\left(-130^{\circ} \mathrm{F}\right.$ and $\left.-76^{\circ} \mathrm{F}\right)$, and a portable refrigeration unit or container that can maintain the temperature at $2^{\circ} \mathrm{C}$ and $8{ }^{\circ} \mathrm{C}\left(36{ }^{\circ} \mathrm{F}\right.$ and $\left.46^{\circ} \mathrm{F}\right)$. Vaccines can be stored until they expire. Vials should be protected from vibration, drop, impact, light, and if possible keep the vaccine vial in an upright position. 33

Store unopened Moderna vaccines at $-50^{\circ} \mathrm{C}$ and $15^{\circ} \mathrm{C}\left(-58^{\circ} \mathrm{F}\right.$ and $\left.50 \mathrm{~F}\right), 2^{\circ} \mathrm{C}$ and $8^{\circ} \mathrm{C}\left(36^{\circ} \mathrm{F}\right.$ and $\left.46^{\circ} \mathrm{F}\right)$ for up to 30 days, $8^{\circ} \mathrm{C}$ and $25^{\circ} \mathrm{C}\left(46^{\circ} \mathrm{F}\right.$ and $\left.770 \mathrm{~F}\right)$ for a total of 24 hours. Store modern vaccine vials that have been opened at a temperature of $2^{\circ} \mathrm{C}$ and $25^{\circ} \mathrm{C}$ $\left(36^{\circ} \mathrm{F}\right.$ and $\left.77 \mathrm{~F}^{\circ}\right)$, use the vaccine a maximum of 12 hours after opening, if it exceeds 12 hours or the vaccine has been used 20 times then it can no longer be used. Should not be stored on dry ice. Storage of 
Janssen vaccine at $2^{\circ} \mathrm{C}$ and $8^{\circ} \mathrm{C}\left(36^{\circ} \mathrm{F}\right.$ and $\left.46^{\circ} \mathrm{F}\right)$. The opened vial can be used for up to 6 hours. The temperature should be checked periodically. Should not be frozen and should be kept out of direct light. 33

\section{Vaccine efficiency on mutations of the COVID-19 virus}

Coronavirus is an RNA virus that spreads widely so that genetically it can change and develop slowly. Mutations in the viral genome sequence give rise to several different variants. Mutagens present in the environment can change the genetic structure of the SARS-CoV-2 virus such as UV light, radiation, iron ions, and endogenous components of organisms. Special supervision by WHO of several new variants that are starting to develop. Alpha, Beta, Gamma, Delta, Epsilon, Zeta, Eta, Theta, Iota, and Kappa variants are divided into 2 groups, namely Variants of Interest (VOIs) and Variants of Concern (VOCs). ${ }^{34}$

Variants of concern consisting of variant Alpha (B.1.1.7) originating from the United Kingdom gave an increase in the incidence of cases from 3\% to $96 \%$ within 5 months. The Beta variant (B.1.351) was discovered in southern Africa in May 2020 and spread to 80 other countries. The E484K mutation makes this variant more lethal because it can escape from the immune system, making this variant more resistant to vaccines. variant can infect younger population groups. Gamma variant (P.1) was discovered in the city of Manaus, Brazil in November 2020. This variant has a higher transmission rate than the previous variant. Variant Delta (B.1.617.2) is the fastest and most dangerous variant, especially infecting populations who have not received the vaccine. First discovered in India, it can be very deadly due to its highly contagious nature up to $60 \%$ compared to the previous variant. The mutation of the Delta variant $\mathrm{S}$ protein created another new variant called Delta Plus, which began to develop and is now widely found in other countries. ${ }^{34}$ The variant of interests consists of various variants including the
Epsilon variant (B.1.427/B.1.429/20C-S:452R), Zeta variant (P.2/20B-S:484K), Eta variant (B.1.525/20AS :484K), Theta variant (P.3/20B-S:265C), Iota variant (B.1.526/20C-S:484K), Kappa variant (B. 1.617.1/21A-S: 154K).34,35

The Technical Advisory Group on SARS-CoV-2 (TAG-VE) is a group of experts who monitor the evolution and combination of viral mutations. TAGVE succeeded in identifying the latest variant, B.1.1529 (Omicron) on November 26, 2021, which was first reported by WHO to come from South Africa. This variant has many types of mutations and some of them result in a higher rate of reinfection compared to other VOC variants. Several laboratories reported that on PCR swab examination, 1 of 3 viral genes could not be detected (dropout $\mathrm{S}$ gene or $\mathrm{S}$ target failure gene) and this became a marker in the identification of omicron variants. 36

The SARS-CoV-2 virus variant has a major impact on vaccine efficacy. Most vaccines work by blocking the fusion of the ACE2 receptor with the S protein, but because of the mutation in the $\mathrm{S}$ protein, the antibodies produced by the vaccine cannot recognize the mutation and the vaccine's efficacy will be reduced. 37

\section{Conclusion}

The SARS-CoV-2 virus is the cause of COVID-19 and has been declared a pandemic by WHO. Prevention is important in reducing the spread of COVID-19 disease, one of which is the use of vaccines, in addition to washing hands, using masks, maintaining distance, and limiting interactions and mobilization. To get a vaccine with a good safety profile, cheap and fast production, and which can provide high effectiveness and efficacy still requires further research. The vaccine strategy is expected to achieve the target of herd immunity to reduce the morbidity and mortality of COVID-19 disease. 


\section{References}

1. World Health Organization. WHO Coronavirus (COVID-19) Dashboard [Internet]. 2021 [cited 2021 Nov 26]. Available from: https:/ / covid19.who.int

2. Huang Q, Zeng J, Yan J. COVID-19 mRNA vaccines. Journal of Genetics and Genomics. 2021 Feb 20; 48(2): 107-14.

3. Samaranayake LP, Seneviratne CJ, Fakhruddin KS. Coronavirus disease 2019 (COVID-19) vaccines: A concise review. Oral Diseases. 2021; 1: 5-9.

4. Randolph HE, Barreiro LB. Herd Immunity: Understanding COVID-19. Immunity. 2020 May 19; 52(5): 737-41.

5. Bartsch SM, O'Shea KJ, Ferguson MC, Bottazzi ME, Wedlock PT, Strych U, et al. Vaccine Efficacy Needed for a COVID-19 Coronavirus Vaccine to Prevent or Stop an Epidemic as the Sole Intervention. American Journal of Preventive Medicine. 2020 Oct 1; 59(4): 493-503.

6. Ritchie H, Mathieu M, Rodés-Guirao L, Appel C, Giattino C, Ortiz-Ospina E, et al. Coronavirus Pandemic (COVID-19) [Internet]. 2021 [cited 2021 Nov 27]. Available from: https: / / ourworldindata.org/coronavirus

7. Committee on COVID-19 Handling and National Economic Recovery. National COVID-19 Vaccination [Internet]. 2021 [cited 2021 Nov 26]. Available from: https://vaccin.kemkes.go.id/\#/vaccines

8. World Health Organization. COVID-19 vaccine tracker and landscape [Internet]. 2021 [cited 2021 Nov 28]. Available from: https: / / www.who.int/publications/m/item /draft-landscape-of-covid-19-candidatevaccines

9. Dai L, Gao GF. Viral targets for vaccines against COVID-19. Nature Reviews
Immunology. 2021 Feb 1: 21(2): 73-82.

10. Ullah H, Ullah A, Gul A, Mousavi T, Khan MW. Novel coronavirus 2019 (COVID-19) pandemic outbreak: A comprehensive review of the current literature. Vacunas. 2021 May 1: 22(2): 106-13.

11. Choudhary J, Dheeman S, Sharma V, Katiyar P, Karn SK, Sarangi MK, et al. Insights of Severe Acute Respiratory Syndrome Coronavirus (SARS-CoV-2) pandemic: a current review. Biological Procedures Online. 2021 Dec 1: 23(1): 1-22.

12. Flanagan KL, Best E, Crawford NW, Giles M, Koirala A, Macartney K, et al. Progress and Pitfalls in the Quest for Effective SARS-CoV2 (COVID-19) Vaccines. Vol. 11, Frontiers in Immunology. Frontiers Media SA; 2020; 1-8.

13. Huang Y, Yang C, Xu Xfeng, Xu W, Liu Swen. Structural and functional properties of SARS-CoV-2 spike protein: potential antiviral drug development for COVID-19. Vol. 41, Acta Pharmacologica Sinica. Springer Nature; 2020; 1141-9.

14. Xia X. Domains and functions of spike protein in sars-cov-2 in the context of vaccine design. Viruses. 2021 Jan 1; 13(1): 1-9.

15. Azkur AK, Akdis M, Azkur D, Sokolowska M, van de Veen W, Brüggen MC, et al. Immune response to SARS-CoV-2 and mechanisms of immunopathological changes in COVID-19. Vol. 75, Allergy: European Journal of Allergy and Clinical Immunology. Blackwell Publishing Ltd; 2020; 1564-81.

16. Sadarangani M, Marchant A, Kollmann TR. Immunological mechanisms of vaccineinduced protection against COVID-19 in humans. Nature Reviews Immunology. 2021 Aug 1: 21(8): 475-84.

17. Saif LJ. Vaccines for COVID-19: Perspectives, Prospects, and Challenges Based On Candidate SARS, MERS, and 
Animal Coronavirus Vaccines. European Medical Journal. 2020 Mar 24; 1: 1-5.

18. Stern PL. Key steps in vaccine development. Annals of Allergy, Asthma and Immunology. 2020 Jul 1: 125(1): 17-27.

19. Kanesa-thasan N, Shaw A, Stoddard JJ, Vernon TM. Ensuring the optimal safety of licensed vaccines: A perspective of the vaccine research, development, and manufacturing companies. Pediatrics. 2011 May;127(1): 2-4.

20. WHO. Vaccine Safety Basics [Internet]. 2021 [cited 2021 Nov 26]. Available from: https: / / in.vaccine-safetytraining.org/home.html

21. COVID-19 Handling Unit. COVID-19 Vaccine Emergency Use Permit [Internet]. 2020 [cited 2021 Nov 30]. Available from: https: / / covid19.go.id/

22. Li Y, Tenchov R, Smoot J, Liu C, Watkins S, Zhou Q. A Comprehensive Review of the Global Efforts on COVID-19 Vaccine Development. Vol. 7, ACS Central Science. American Chemical Society; 2021; 512-33.

23. Chauhan N, Soni S, Gupta A, Aslam M, Jain U. Interpretative immune targets and contemporary position for vaccine development against SARS-CoV-2: A systematic review. Journal of Medical Virology. 2021 Apr 1; 93(4): 1967-82.

24. Kyriakidis NC, López-Cortés A, González EV, Grimaldos AB, Prado EO. SARS-CoV-2 vaccines strategies: a comprehensive review of phase 3 candidates. npj Vaccines. 2021 Dec $1 ; 6(1)$ : 1-17.

25. Defendi HGT, da Silva Madeira L, Borschiver S. Analysis of the COVID-19 Vaccine Development Process: an Exploratory Study of Accelerating Factors and Innovative Environments. Journal of Pharmaceutical Innovation. $2021 \mathrm{Feb} 2 ; 1$ : 2-5.
26. He Q, Mao Q, Zhang J, Bian L, Gao F, Wang $\mathrm{J}$, et al. COVID-19 Vaccines: Current Understanding on Immunogenicity, Safety, and Further Considerations. Vol. 12, Frontiers in Immunology. Frontiers Media SA; 2021; 2-9.

27. Ewen Callaway. The Race for Covid Vaccine. Springer Nature Limited. 2020 Apr 30; 580: $1-2$.

28. Fathizadeh $H$, Afshar S, Masoudi MR, Gholizadeh P, Asgharzadeh M, Ganbarov K, et al. SARS-CoV-2 (Covid-19) vaccines structure, mechanisms and effectiveness: A review. Vol. 188, International Journal of Biological Macromolecules. Elsevier BV; 2021. p. 740-50.

29. Anand P, Stahel VP. Review of the safety of Covid-19 mRNA vaccines: a review. Patient Safety in Surgery. 2021 Dec 1; 15(1): 1-9.

30. Vitiello A, Ferrara F. Brief review of the mRNA vaccines COVID-19. Inflammopharmacology. 2021 Jun 1;29(3):645-9.

31. Zhang C, Maruggi G, Shan H, Li J. Advances in mRNA vaccines for infectious diseases. Frontiers in Immunology. 2019; 10: 3-5.

32. Kounis NG, Koniari I, de Gregorio C, Velissaris D, Petalas K, Brinia A, et al. Allergic reactions to current available covid19 vaccinations: Pathophysiology, causality, and therapeutic considerations. Vaccines. 2021; 9(3): 1-19.

33. Centers for Disease Control and Prevention. Vaccine Storage and Handling Toolkit [Internet]. 2021 [cited 2021 Nov 28]. Available from: https://www.cdc.gov/vaccines/hcp/admin/ storage/toolkit/

34. Roy B, Dhillon J, Habib N, Pugazhandhi B. Global variants of COVID-19: Current understanding. Journal of Biomedical Sciences. 2021 Jul 16; 8(1): 8-11. 
35. Vasireddy D, Vanaparthy R, Mohan G, Malayala SV, Atluri P. Review of COVID-19 Variants and COVID-19 Vaccine Efficacy: What the Clinician Should Know? Journal of Clinical Medicine Research. 2021 Jun 1; 13(6): 317-25.

36. World Health Organization. Classification of Omicron (B, 1, 1,529): SARS-CoV-2 Variant of Concern [Internet]. 2021 [cited 2021 Nov 29]. Available from: https://www.who.int/news /item/26-112021-classification-of-omicron-(b. 1.1.529)sars-cov-2-variant-of-concern

37. Hossain MK, Hassanzadeganroudsari M, Apostolopoulos V. The emergence of new strains of SARS-CoV-2. What does it mean for COVID-19 vaccines? Expert Review of Vaccines. 2021; 20(6): 635-8. 